Iraq J Pharm

Vol. 14, No.1, 2014

\title{
Comparison of the effect of losartan versus candasartan on uric acid levels in hypertensive patients
}

\author{
Zeina A Munim Al-Thanoon \\ Department of Pharmacology and Toxicology, College of Pharmacy \\ University of Mosul, Mosul- Iraq, Correspondence: zeinaalkazaz@yahoo.com
}

\begin{abstract}
Received
Accepted

14.1.2014

4.3.2014

ABSTRACT
\end{abstract}

Background: It have been suggested by some studies that uric acid plays a causal role in the development of cardiovascular disease where as other studies concluded that uric acid merely reflects other concomitant risk factors, such as hypertension, insulin resistance, obesity, or lipid abnormality . Sartan drugs or angiotensin II receptor blockers do appear to lower uric acid levels (SUA). The clinical importance of this finding to patients with hypertension, or gout, or both is not yet known. The present study was aimed to compare the effects of the antihypertensive drugs losartan and candasartan on blood pressure and uric acid level in hypertensive patients.

Materials and Methods: A total of 80 newly diagnosed hypertensive patients were divided into two groups, with 40 patients in each group. Group 1 was given losartan (50 $\mathrm{mg} /$ day) and group 2 was given candasartan ( $8 \mathrm{mg} /$ day). A control group of 50 apparently healthy individuals was included. Blood pressure and uric acid were measured for controls and patients before and after drug administration.

Results: A significant increase in blood pressure and uric acid were found in hypertensive patients before starting treatment $(\mathrm{P}<0.001)$, as compared with controls. After 2 months of treatment, the systolic and diastolic BP were significantly reduced in the both losartan and candasartan groups $(\mathrm{P}<0.001)$. Both drugs were similarly effective in reducing the blood pressure in patients with hypertension with no statistical significant difference between the two treatments. Serum uric acid levels were only significantly reduced after 2 months of treatment with losartan $(\mathrm{P}<0.001)$ but not with candasartan.

Conclusions: Our findings suggest that both losartan and candasartan therapy were similarly effective in reducing blood pressure in patients with hypertension. Losartan, but not candasartan, was associated with a significant reduction in serum uric acid levels. Our findings suggest that the losartan is the drug of choice in patients with hypertension and hyperuricemia and gout.

Key Words: Hypertension, hyperuricemia, losartan, candasartan.

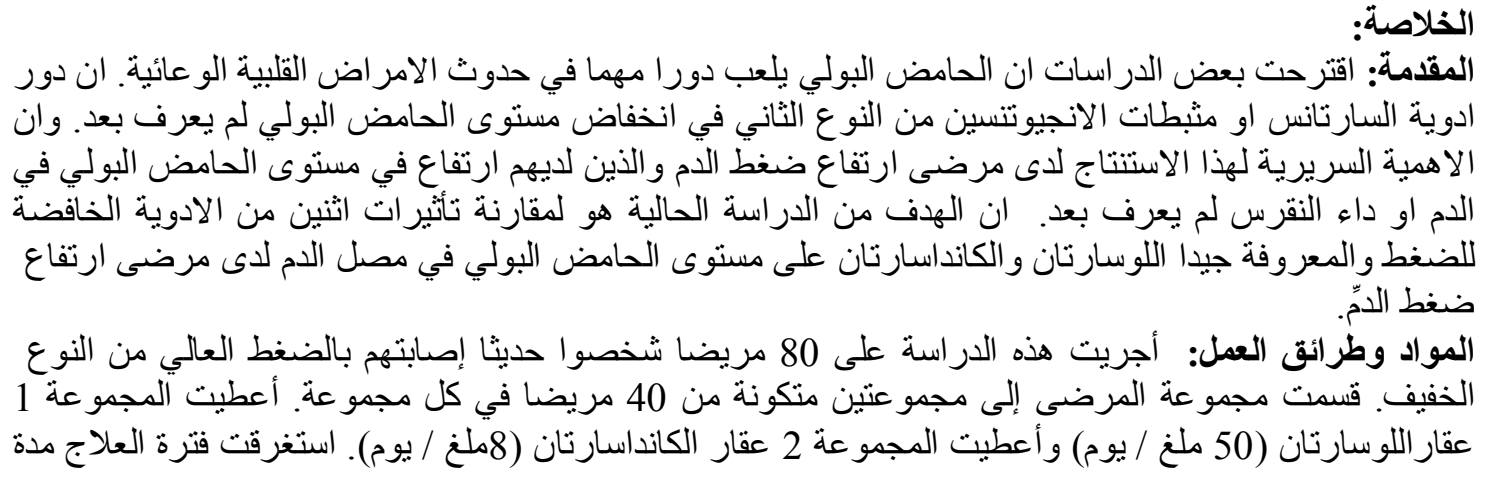


شهرين. تم اختيار 50 شخصا سليما من المتطو عين (بيدون أصحاء) طبيعي الضغط ليكونوا مجمو عة الضبط. تم

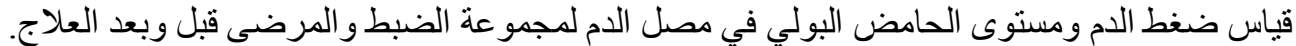

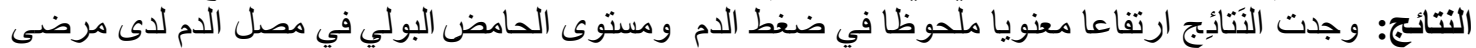

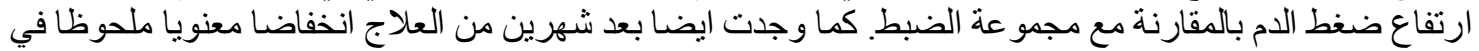

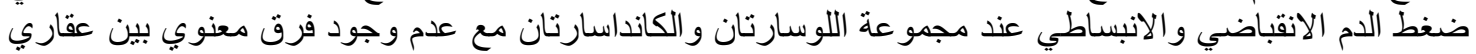

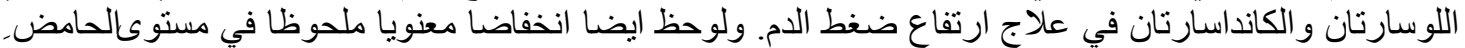

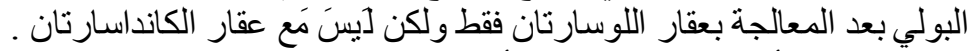

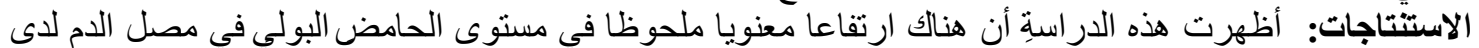

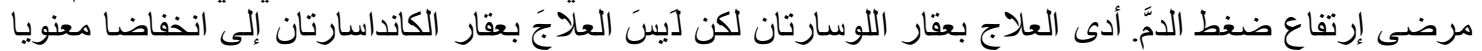

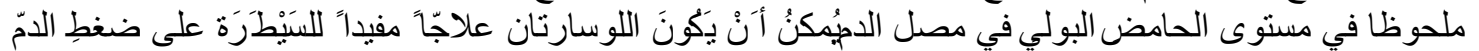

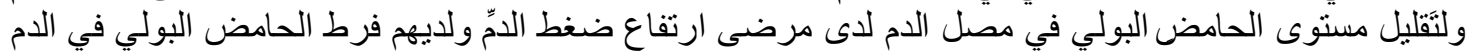
وداء النقرس. الكلمات المفتاحية: ارتفاع ضغط الدم، فرط الحامض البولي بالدم، اللوسارتان، الكانداسارتان.

$I^{\prime}$ have been suggested by some studies that uric acid plays a causal role in the development of cardiovascular disease ${ }^{1}$ where as other studies concluded that uric acid merely reflects other concomitant risk factors, such as hypertension, insulin resistance, obesity, or lipid abnormality ${ }^{2,3}$. Many drugs have hypouricemic properties, in addition to their main therapeutic effects. The oral weight loss agent sibutramine decreases serum uric acid in obese patients by $20 \%$ to $25 \%{ }^{4}$. Similarly, in patients with type 2 diabetes and hyperuricemia, the insulin sensitizing agent troglitazone lowers serum uric acid by $20 \%$ to $25 \%{ }^{5}$. Ramipril was found to increase the excretion of uric acid in a number of hypertensive patients 6 . There is observational data suggesting that sartans or angiotensin II receptor blocker (ARB), may affects SUA level ${ }^{7}$ .The effects of the antihypertensive drugs, sartans, on serum uric acid level (SUA) is not well studied. The present study was conducted to compare the effects of losartan and candasartan on uric acid levels in hypertensive patients.

\section{Patients And Methods}

A total of eighty newly diagnosed patients with mild hypertension (Blood pressure $\geq 140 / 90 \mathrm{mmHg})^{8}$,were participated in this study. They were selected from the out-patient clinic in IBN-SINA teaching hospital in Mosul city. The study protocol was approved by regional Research Ethics Committees at the College of Pharmacy and Mosul Health Administration. The study was an open, controlled, comparative, clinical trial of two months duration.

The patients were divided into two groups each of 40 patients. Group 1 was given losartan $50 \mathrm{mg}$ orally once daily for 2 months (Angizar ${ }^{\circledR} 50 \mathrm{mg}$, Micro pharmaceutical industries, Co. Ltd., India) . They were 14 males and 26 females, with a mean age of 55.42 \pm 7.97 years. Group 2 received candasartan 8 mg orally once daily oral dose for 2 months (Atacand ${ }^{\circledR} 8 \mathrm{mg}$, AstraZeneca pharmaceutical industries, Co. Ltd., Sweden). They were 19 males and 21 females with mean ages of $54.22 \pm 6.45$ years. Another 50 healthy individuals matched in age and gender with study patients also participated in the study as a control group. They were 27 males and 23 females in this group with mean age of $53.4 \pm 9.15$ years.

Those with hepatic or renal diseases, pregnancy and lactation, and hypertensive patients on 
antihypertensive therapy were excluded. Blood pressure was measured at baseline by standard mercury sphygmomanometer and at the end of 2 months treatment period with losartan or candasartan. Goal blood pressure after treatment was less than $140 / 90 \mathrm{mmHg}$. Serum uric acid was measured before and after losartan or candasartan administration by standard commercial kits by using a kit supplied from Biolabo (France) $)^{9}$.

All values are quoted as the mean \pm SD. Paired t-test was used to compare blood pressure and serum uric acid concentrations at baseline and after treatment. Unpaired t-test was used to compare serum uric acid concentrations between control and patient groups and between losartan and candasartan groups. The statistical results were considered significant at $\mathrm{p} \leq 0.05^{10}$.

\section{Results}

The systolic blood pressure (SBP) and diastolic blood pressure (DBP) were significantly higher $(p<0.001)$ in hypertensive patients before starting therapy with either losartan or candasartan in comparison with the control group (Table 1 and 3, respectively). After 2 months, the systolic and diastolic blood pressure were reduced in the losartan group from
$151.2 \pm 7.72$ to $138.0 \pm 7.14 \mathrm{mmHg}$ and from $89.3 \pm 6.21$ to $80.2 \pm 5.84 \mathrm{mmHg}$ respectively, $(\mathrm{P}<0.001)$ (Table 2$)$, and in the candasartan group from $140.78 \pm 5.93 \mathrm{mmHg}$ at baseline to $125.47 \pm 8.28 \mathrm{mmHg}$, and from $91.44 \pm 6.15$ to $82.08 \pm 5.23 \mathrm{mmHg}$ respectively, $(\mathrm{P}<0.001)$ (Table 4). It has been found that losartan was as effective as candasartan in lowering systolic and diastolic blood pressure, (Table 5).

Baseline uric acid levels were $297.70 \pm 61.69 \mu \mathrm{mol} / 1$ for losartan group and $\quad 300.86 \pm 54.70 \mu \mathrm{mol} / 1 \quad$ for candasartan group which showed a significant elevation $(\mathrm{P}<0.001)$ as compared with the control $(280.87 \pm 66.52 \mu \mathrm{mol} / \mathrm{l})$ (Table 1 and 3 , respectively). Comparison of uric acid levels before and after 2 months of therapy by each drug showed a significant reduction in losartan group $(288.42 \pm 40.63 \mu \mathrm{mol} / \mathrm{l})(\mathrm{P}<0.001)($ Table 2 ) and a non significant increase in the candasartan group (305.65 \pm 52.31 $\mu \mathrm{mol} / \mathrm{l}) \quad(\mathrm{p}=0.324) \quad($ Table 4$)$. Comparison of uric acid levels between losartan group and candasartan group showed a significant reduction in the SUA levels in the losartan group ($9.28 \pm 1.06 \mu \mathrm{mol} / 1, \mathrm{P}<0.001)$ as compared with the candasartan group $(4.79 \pm 9.86)$ (Table 5).

Table 1. Comparison of blood pressure and uric acid between control and losartan group

\begin{tabular}{|c|c|c|c|}
\hline \multirow{2}{*}{ Parameter } & \multicolumn{3}{|c|}{ Mean \pm SD } \\
\cline { 2 - 4 } & $\begin{array}{c}\text { Control } \\
(\mathbf{n}=\mathbf{5 0})\end{array}$ & $\begin{array}{c}\text { Before Drug } \\
(\mathbf{n}=\mathbf{4 0})\end{array}$ & $\begin{array}{c}\text { After Drug } \\
(\mathbf{n}=\mathbf{4 0})\end{array}$ \\
\hline $\mathrm{SBP}(\mathrm{mm} \mathrm{Hg})$ & $129.05 \pm 6.93$ & $151.2 \pm 7.72^{* * *}$ & $138.0 \pm 7.14$ \\
\hline $\mathrm{DBP}(\mathrm{mm} \mathrm{Hg})$ & $78.32 \pm 4.91$ & 89.3 to $\pm 6.21^{* * *}$ & $80.2 \pm 5.84$ \\
\hline Uric acid $(\mu \mathrm{mol} / \mathrm{l})$ & $280.87 \pm 66.52$ & $297.70 \pm 61.69^{* * *}$ & $288.42 \pm 40.63^{*}$ \\
\hline
\end{tabular}

* Significant difference from control at $\mathrm{p}<0.05$ and and $* * *$ at $\mathrm{p}<0.001$ using unpaired t-test 
Table 2. The effect of losartan on blood pressure and uric acid

\begin{tabular}{|c|c|c|c|}
\hline \multirow{2}{*}{ Parameter } & \multicolumn{3}{|c|}{ Mean \pm SD } \\
\cline { 2 - 4 } & Before & After & p-value \\
\hline SBP(mm Hg) & $151.2 \pm 7.72$ & $138.0 \pm 7.14$ & $<0.001$ \\
\hline DBP(mm Hg) & 89.3 to \pm 6.21 & $80.2 \pm 5.84$ & $<0.001$ \\
\hline Uric acid $(\mu \mathrm{mol} / 1)$ & $297.70 \pm 61.69$ & $288.42 \pm 40.63$ & $<0.001$ \\
\hline
\end{tabular}

Using paired t- test $(n=40)$.

Table 3. Comparison of blood pressure and uric acid between control and candasartan group

\begin{tabular}{|c|c|c|c|}
\hline \multirow{2}{*}{ Parameter } & \multicolumn{3}{|c|}{ Mean \pm SD } \\
\cline { 2 - 4 } & $\begin{array}{c}\text { Control } \\
(\mathbf{n}=\mathbf{5 0})\end{array}$ & $\begin{array}{c}\text { Before Drug } \\
(\mathbf{n}=\mathbf{4 0})\end{array}$ & $\begin{array}{c}\text { After Drug } \\
(\mathbf{n}=\mathbf{4 0})\end{array}$ \\
\hline $\mathrm{SBP}(\mathrm{mm} \mathrm{Hg})$ & $129.05 \pm 6.93$ & $140.78 \pm 5.93 * * *$ & $125.47 \pm 8.28$ \\
\hline $\mathrm{DBP}(\mathrm{mm} \mathrm{Hg})$ & $78.32 \pm 4.91$ & $91.44 \pm 6.15^{* * *}$ & $82.08 \pm 5.23$ \\
\hline Uric acid $(\mu \mathrm{mol} / \mathrm{l})$ & $280.87 \pm 66.52$ & $300.86 \pm 54.70^{* * *}$ & $305.65 \pm 52.31 * * *$ \\
\hline
\end{tabular}

$* * *$ Significant difference from control at $\mathrm{p} \leq 0.001$ using unpaired $\mathrm{t}$ - test.

Table 4. The effect of candasartan on blood pressure and uric acid

\begin{tabular}{|c|c|c|c|}
\hline \multirow{2}{*}{ Parameter } & \multicolumn{3}{|c|}{ Mean \pm SD } \\
\cline { 2 - 4 } & Before & After & p-value \\
\hline SBP(mm Hg) & $140.78 \pm 5.93$ & $125.47 \pm 8.28$ & $<0.001$ \\
\hline DBP(mm Hg) & $91.44 \pm 6.15$ & $82.08 \pm 5.23$ & $<0.001$ \\
\hline Uric acid $(\mu \mathrm{mol} / \mathrm{l})$ & $300.86 \pm 54.70$ & $305.65 \pm 52.31$ & $0.324(\mathrm{NS})$ \\
\hline
\end{tabular}

Using paired t- test $(\mathrm{n}=40)$. NS $=$ Non significant

Table 5. Comparison of percent variation of the studied parameters after therapy with losartan or candasartan

\begin{tabular}{|c|c|c|c|}
\hline \multirow{2}{*}{ Parameter } & \multicolumn{2}{|c|}{ Mean \pm SD (\%) } & \multirow{2}{*}{ p-value } \\
\cline { 2 - 3 } & $\begin{array}{c}\text { Losartan } \\
(\mathbf{n = 4 0 )}\end{array}$ & $\begin{array}{c}\text { Candasartan } \\
(\mathbf{n = 4 0 )}\end{array}$ & \\
\hline $\mathrm{SBP}(\mathrm{mm} \mathrm{Hg})$ & $-13.20 \pm 0.58$ & $-15.31 \pm 2.35$ & $0.164(\mathrm{NS})$ \\
\hline $\mathrm{DBP}(\mathrm{mm} \mathrm{Hg})$ & $-9.10 \pm 0.73$ & $-9.36 \pm 0.92$ & $0.241(\mathrm{NS})$ \\
\hline Uric acid $(\mu \mathrm{mol} / \mathrm{l})$ & $-9.28 \pm 1.06$ & $4.79 \pm 9.86$ & $<0.001$ \\
\hline
\end{tabular}

$\mathrm{NS}=$ Not significant using unpaired t-test

Negative sign means decrease. 


\section{Discussion}

The present study demonstrates significantly higher serum uric acid levels in patients with hypertension in comparison with the control group. These results are in consistent with the results obtained from many studies which also demonstrate increased levels of uric acid in patients with hypertension ${ }^{11}$. Several mechanisms were attributed to the increase of serum uric acid levels in patients with hypertension. The increase in serum uric acid in hypertension may be due to the decrease in renal blood flow that accompanies the hypertensive state, since a low renal blood flow will stimulate urate reabsorption ${ }^{12}$. and results in microvascular disease ${ }^{13}$. Proximal tubular reabsorption of serum uric acid occurs by an active transport mechanism closely linked to or identical with the tubular reabsorption of sodium $^{14}$. Another mechanism for the increased serum uric acid levels in hypertension is that hypertension is associated with increased oxidative stress $^{15}$. Because uric acid is considered to be an effective antioxidant. The elevated serum uric acid levels encountered in individuals with hypertension may reflect a compensatory mechanism counteracting the increased oxidative stress associated with the hypertension ${ }^{16}$.

In the present study, only losartan causes a significant reduction of serum uric acid concentrations in patients with hypertension after 2 months of therapy. These data are compatible with previous findings that suggested that losartan have urate lowering properties and indicated that losartan have uricosuric effects. Many studies have demonstrated that the uricosuric effect of losartan was due to the parent compound and not to the active metabolite EXP 3174 and that this effect is independent of angiotensin II receptor blockade and is due to unique biochemical properties of losartan $n^{17,18}$. The hypouricemic effect of losartan may be due to that losartan target the urate anion exchange and diminish urate reabsorption in the proximal convoluted tubule; as a result, the urate excretion fraction is increased by $13 \%-30 \%$ and increases renal uric acid excretion ${ }^{19}$. This aspect of losartan therapy might have therapeutic advantages by reducing the risk of elevated uric acid in patient with hypertension, since elevated serum uric acid levels in patient with hypertension regarded as a risk factor for the development of cardiovascular diseases and may ameliorate hyperuricemia induced by other drugs ${ }^{20}$.

The ARBs candesartan and valsartan did not affect the SUA level ${ }^{21}$. In a study of 1161 hypertensive patients, candesartan slightly but significantly increased the SUA level 22. Data obtained from the present study showed that candasartan produce non significant effects on uric acid concentration in patients with hypertension. These finding were in consistent with results obtained by Manolis et al., ${ }^{22}$. Rise in serum uric acid levels reported by Rayner et al., ${ }^{23}$ and Berni et al ${ }^{24}$.

Since losartan have a beneficial effects on blood pressure and serum uric acid concentration, it could be considered the antihypertensive drug of choice in patients with hypertension and hyperuricaemia or gout.

In conclusions, this study demonstrates that both losartan and candasartan therapy were similarly effective in reducing blood pressure in patients with mild hypertension. Losartan, but not candasartan, was associated with a reduction in serum uric acid levels. Therefore, our findings 
suggest that losartan may be the drug of choice in patients with hypertension and hyperuricemia or gout.

\section{References}

1. Tatli E, Aktoz M, Buyuklu $M$ et al. The relationship between coronary artery disease and uric acid levels in young patients with acute myocardial infarction. Cardiol J 2008;15:21-25.

2. Niskanen LK, Laaksonen DE, Nyyssonen K, et al. Uric acid level as a risk factor for cardiovascular and all-cause mortality in middle-aged men: a prospective cohort study. Arch Intern Med. 2004;164:1546-51.

3. Feig DI, Kang DH, Johnson RJ. Uric acid and cardiovascular risk. $\mathrm{N}$ Engl J Med 2008;359:1811-21.

4. Andersson C, Weeke P, Brendorp $B$, et al. Differential changes in serum uric acid concentrations in sibutramine promoted weight loss in diabetes: results from four weeks of the lead-in period of the SCOUT trial. Nutrition \& Metabolism 2009; 6:42.

5. Iwatani M, Wasada T, Katsumori K, et al. Troglitazone decreases serum uric acid concentrations in type II diabetic patients and non diabetics. Diabetologia 2000; 43: 814-815.

6. Labeeuw M, Pozet N, Zech PY, et al. Influence of acute administration of ramipril on the excretion of uric acid. Arch mal Coeur Vaiss 1987;80: 870874.

7. Iwanaga $T$, Sato $M$, Maeda $T$, et al. Concentration-Dependent Mode of Interaction of Angiotensin II Receptor Blockers with Uric Acid Transporter. JPET 2007; 320:211-217.

8. Chobanian AV, Bakris GL, Black HR, et al. The Seventh Report of the Joint National Committee on Prevention, Detection, Evaluation, and Treatment of
High Blood Pressure: the JNC 7 report. JAMA 2003;289: 2560-2572.

9. Fossati P, Prencipe L, Berti G. Use of 3,5-dichloro-2-Hydroxybenzene sulfonic acid -4 Amino phebazone chromogenic system in direct enzymatic assays of uric acid in serum and urine. Clin Chem, 1980; 26:227-231.

10. Armitage P, Berry G. Statistical methods in chemical research.2nd ed. Blackwell, Oxford, London, United Kigdom, 1985;60-75.

11. Johnson RJ, Feig DI, Herrera Acosta J, et al. Resurrection of uric acid as a causal risk factor in essential hypertension. Hypertension $2005 ; 45$ : 18 20.

12. Messerli FH, Frohlich ED, Dreslinski GR, et al. Serum uric acid in essential hypertension: an indicator of renal vascular involvement.Arch Intern Med 1980;93:817-821.

13. Puig JG, Ruilope LM. Uric acid as a cardiovascular risk factor in arterial hypertension. J Hypertens 1999;17:869872.

14. Choi HK, Mount DB, Reginato AM. Pathogenesis of Gout .Ann Intern Med. 2005;143:499-516.

15. Madamanchi NR, Vendrov A, Runge MS. Oxidative stress and vascular disease. Arterioscler Thromb Vasc Biol 2005;25:29-38.

16. Nieto FJ, Iribarren $C$, Gross $M D$, et al. Uric acid and serum antioxidant capacity: a reaction to atherosclerosis? Atherosclerosis 2000;148:131-139.

17. Liberopoulos EN, Christides D, Elisaf M. Comparative effects of losartan and irbesartan on serum uric acid in hypertensive patients with hyperuricemia and gout. J Hypertens 2002; 20:347-351.

18. Alderman M, Aiyer KJ. Uric acid: role in cardiovascular disease and effects of losartan. Curr Med Res Opin 2004; 20:369-379. 
19. John DB, Mike AC. Serum Uric acid-lowering therapies: where are we heading in management of hyperuricaemia and the potential role of uricase. Curr Rheum rep 2004;6:240247.

20. Puddu PE, Lanti M, Menotti A, et al. Serum uric acid for short-term prediction of cardiovascular disease incidence in the Gubbio population Study. Gubbio Study Research Group. Acta Cardiol 2001; 56:243-251.

21. Elliott WJ, Calhoun DA, DeLucca PT, et al. Losartan versus valsartan in the treatment of patients with mild to moderate essential hypertension: data from a multicenter, randomized, doubleblind, 12-week trial. Clin Ther 2001 ;23:1166-1179.
22. Manolis AJ, Grossman E, Jelakovic B, et al. Effects of losartan and candesartan monotherapy and losartan/hydrochlorothiazide combination therapy in patients with mild to moderate hypertension: Losartan Trial Investigators. Clin Ther 2000;22: 1186-1203.

23. Rayner BL, Trinder YA, Baines D, et al. Effect of losartan versus candesartan on uric acid, renal function, and fibrinogen in patients with hypertension and hyperuricemia associated with diuretics. Am J Hypertens 2006;19:208-213.

24. Berni A, Boddi M, Fattori E B, et al. Serum Uric Acid Levels and Renal Damage in Hyperuricemic Hypertensive Patients Treated With ReninAngiotensin System Blockers Am J Hypertens 2010;23(6): 675-680. 